Фармакологічні дослідження біологічно активних речовин

Pharmacological researches of biologically active substances

Рекомендована д. мед. наук, профр. К. А. Посоховою

УДК 615.262.1:616.721-001.7:615.454:547.459.5

\title{
ДОСЛІДЖЕННЯ ВПЛИВУ КОМБІНАЦІї ГЛЮКОЗАМІНУ 3 КЕТОПРОФЕНОМ У ФОРМІ КРЕМ-ГЕЛЮ НА СПОНТАННУ БОЛЬОВУ РЕАКЦІЮ В ЩУРІВ
}

\author{
(CH. В. Давішня, І. А. Зупанець, С. К. Шебеко \\ Національний фрармацевтичний університет, Харків
}

\begin{abstract}
Резюме: дослідження анальгетичної активності комбінації глюкозаміну з кетопросреном у фрормі крем-гелю було проведено на моделі гострого експериментального артриту в щурів. За отриманими даними, досліджуваний препарат чинить позитивний вплив на перебіг спонтанної больової реакції в щурів та має виражену анальгетичну активність.
\end{abstract}

Ключові слова: глюкозамін, кетопрофен, крем-гель, спонтанна больова реакція, анальгетична активність.

Вступ. Остеоартроз (ОА) - хронічне дегенеративно-дистрофрічне захворювання суглобів, що характеризується прогресуючою деструкцією суглобового хряща, проліферативною реакцією хрящової і кісткової тканин і супроводжується реактивним синовіїтом $[4,8]$. Дане захворювання $€$ одним 3 найпоширеніших у структурі патології опорно-рухової системи: розповсюдженість ОА в популяції складає до 14 \% дорослого населення [11]. Відповідно до Міжнародної класифрікації хвороб X перегляду, дану патологію розділяють на: поліартроз (включає артроз більше як одного суглоба), коксартроз (артроз кульшового або тазостегнового суглоба), гонартроз (артроз колінного суглоба), артроз першого зап'ястково-п'ясткового суглоба та ін. Частота уражень окремих суглобів при АО не однакова [5]. Суглобовий синдром при ОА характеризується наявністю больового синдрому - біль посилюється в другій половині дня, до вечора, після фрізичного навантаження [8]. 3 метою покращення якості життя пацієнта раціонально використовувати препарати, що могли б корегувати больовий синдром, такі як ненаркотичні анальгетики та нестероїдні протизапальні препарати (НПЗП) [4]. Але усувати тільки больовий синдром при остеоартрозі недостатньо, оскільки захворювання полягає в порушенні метаболізму хрящової тканини. Тому на сьогодні, за рекомендацією «Європейської антиревматичної ліги» (EULAR), у схеми лікування пацієнтів з ОА включено симптоматичні препарати уповільненої дії (глюкозамін (ГА), хондроїтину сульфрат (ХC), діацереїн, неомилювані сполуки авокадо/сої, гіалуронова кислота) [13]. А комбінування двох вищеописаних груп дозволяє впливати як на больовий синдром при даній патології, так і на метаболізм суглобового хряща [1, 2]. Біль при остеоартрозі є постійним і може турбувати хворого навіть вночі, тому необхідна лікарська форма, що мала б зручне використання та високу швидкість знеболювання в ділянці нанесення [1].
Такі топічні лікарські фрорми, як гель, крем та кремгель мають зазначені властивості [1]. Метою даного дослідження стало встановлення анальгетичних властивостей нового комбінованого протиартрозного препарату - комбінації глюкозаміну з кетопрофеном, співвідношенням 2,5:1, в фрормі крем гелю (Г/К крем-гель ), при відтворенні спонтанної больової реакції у щурів, на тлі розвитку гострого артриту колінного суглоба.

Методи дослідження. Дослідження впливу препарату Г/К крем-гель на перебіг спонтанної больової реакції за умов розвитку гострого експериментального артриту проводили на 40 білих нелінійних щурах, яких розподіляли на 4 дослідні групи по 10 тварин:

1 група - тварини з артритом, що нашкірно отримували Г/К крем-гель в умовно-терапевтичній дозі 50 г;

2 група - тварини 3 артритом, що нашкірно отримували Фастум гель в еквівалентній дозі;

3 група - тварини 3 артритом, що нашкірно отримували Глюкозамін крем-гель в еквівалентній дозі;

4 група - тварини 3 артритом, що нашкірно отримували препарат Хондроксид в еквівалентній дозі.

Всі піддослідні тварини утримувались у віварії ЦНДЛ Національного фрармацевтичного університету, згідно із стандартними санітарними нормами, на необхідному харчовому раціоні [7]. Усі дослідження проводились у відповідності з директивою Ради ЄС 86/609 ЄЄС від 24 листопада 1986 р. про дотримання законів, постанов та адміністративних положень держав ЄС з питань захисту тварин, що використовуються для експериментальної та іншої наукової мети [14]. На початку експерименту всіх тварин піддавали наркозу, шляхом внутрішньоочеревинного введення розчину фенобарбіталу у дозі 40 мг/кг, при цьому орієнтовна тривалість наркозного сну складала 1,0-1,5 години [12].

Після втрати свідомості у всіх тварин проводили видалення волосяних покровів на площі приблизно

ISSN 2312-0967. Фармацевтичний часопис. 2015. № 2 
2 см² $^{2}$ на ділянках шкіри в області колінних суглобів на обох задніх лапах. Далі негайно проводили відтворення гострого артриту колінного суглоба на правій задній лапі шляхом внутрішньосуглобового введення 25 мкл 2\% розчину $\lambda$-карагеніну (Sigma, США), виготовленого асептично на фрізіологічному розчині. У колінний суглоб лівої задньої лапи вводили еквівалентну кількість фрізіологічного розчину $[6,10,12]$.

Через 5 годин після відтворення патології і далі щоденно протягом 5 діб у всіх тварин проводили одноразове нанесення дослідних м'яких фрорм на обидві задні лапи, шляхом нашкірних аплікацій в еквівалентних умовно-терапевтичних дозах по 50 мг. Препарати наносили на площу приблизно $2 \mathrm{~cm}^{2}$ в ділянці колінних суглобів на обох задніх лапах при ретельному втиранні та виключенні можливості їх злизування 3 поверхні шкіри тваринами. Вимірювання інтенсивності спонтанної больової реакції проводили станом на 1, 3 та 5 добу дослідження за 30 хвилин та через 1 годину після нанесення дослідних засобів. Для цього кожну тварину поміщали до фріксуючої камери «тестера інвалідності» - Incapacitance Tester MkV («Linton Instrumentation», Великобританія) та витримували там протягом 5 хвилин для акліматизації, поки тварина не адаптується та прийме зручне положення. При цьому задні кінцівки щура повинні були знаходитись на навантажувальних пластинах приладу, кожна окремо, а передні кінцівки - на похилій передній стінці камери $[6,15,16]$. Таким чином, вся маса тварини перерозподілялась через задні кінцівки на вагові датчики «тестеру інвалідності». Вимірювання перерозподілу маси тіла тварини проводили тричі 3 інтервалом у 5 секунд та фріксували середнє значення маси тіла, що приходиться на праву та ліву кінцівку окремо. Далі розраховували індекс інвалідності (II) $[16,17]$ :

$$
\mathrm{II}=\frac{\text { Мпк }}{\text { Мпк }+ \text { Млк }}
$$

де II - індекс інвалідності (у.о.);

Мпк - маса тіла тварини, що розподіляється на праву (пошкоджену) кінцівку;

Млк - маса тіла тварини, що розподіляється на ліву (здорову) кінцівку.

Анальгетичну активність визначали за здатністю досліджуваних засобів зменшувати інтенсивність спонтанної больової реакції у тварин [12], що проявлялось у збільшенні II у порівняні з вихідними даними та виражали у відсотках:

$$
\mathrm{AA}=\frac{\Pi_{2}-\Pi_{1}}{\Pi_{1}} \times 100 \%
$$

де AА - анальгетична активність у \%;

$\mathrm{II}_{1}$ - значення індексу інвалідності у групі дослідних тварин до введення лікарського засобу;
$\mathrm{II}_{2}$ - значення індексу інвалідності у групі дослідних тварин після введення лікарського засобу.

Статистичну обробку отриманих результатів проводили методами варіаційної статистики з використанням t-критерію Стьюдента й непараметричних методів аналізу (Mann-Whitney U Test) за допомогою комп'ютерних програм STATISTICA 7.0 та MS Exel 2007 [9] і представляли у вигляді порівняльних таблиць із результатами різних груп.

Результати й обговорення. Результати дослідження впливу Г/К крем-гелю на інтенсивність спонтанної больової реакції у щурів 3 гострим карагеніновим артритом, наведені у таблиці 1, свідчать, що досліджувана комбінація чинить виражену анальгетичну дію, оскільки значно збільшує ІІ протягом всього періоду спостережень.

Найвищими в представленому дослідженні були такі показники АA: станом на 1 добу досліджень 41,79 \%, на 3 добу - 47,92 \% та на 5 добу 62,23 \%, котрі за виразністю дії, починаючи 33 доби, достовірно перевищували препарати порівняння.

Високий рівень АА досліджуваного препарату пояснюється тим, що комбінація глюкозаміну з кетопрофреном має як аналгетичну і протизапальну дію, так і здатність поліпшувати метаболізм суглобового хряща, за рахунок усунення недостатності глюкозаміногліканів [2]. Слід відмітити, що збільшення рівня АА дослідного препарату пояснюється не тільки потенціюючим впливом його повторних нанесень, але й зниженням рівня II у процесі експерименту, що говорить про зменшення спонтанних больових відчуттів тварин внаслідок згасання патофрізіологічних проявів гострого артриту.

Аналогічна картина, але при меншому ступені виразності, спостерігалась під впливом референспрепарату Фастум гель. Так, рівень його АA на 1 добу спостережень склав 36,73 \%, на 2 добу - 35,34 \% і на 5 добу - 42,05 \%. Слід відмітити, що за рівнем АA на 3 та 5 добу дослідження Фастум гель вірогідно поступався активності досліджуваної комбінації. Дана ситуація пояснюється явищем синергізму при застосуванні НПЗП та хондропротекторів [2].

При застосуванні препарату порівняння Глюкозамін крем-гель 31 по 5 добу спостерігався мінімальний рівень анальгетичної активності, який наприкінці експерименту склав 17,06 \%. Низький рівень аналгетичної активності даного препарату порівняння $є$ очікуваним, оскільки монопрепарати хондропротекторів не володіють прямою анальгетичною активністю.

Щодо препарату порівняння Хондроксид, його анальгетична активність $є$ трохи вищою і достовірно відрізняється від Глюкозамін крем-гелю. На 5 добу вона становить 21,07 \%. Вірогідно, така ситуація пояснюється наявністю допоміжної речовини диметилсульфроксиду у складі препарату, який має протизапальну та місцевоанестезуючу дію [3]. 
Фармакологічні дослідження біологічно активних речовин Pharmacological researches of biologically active substances

Таблиця 1. Вплив препарату Г/К крем-гель та рефрерентних об'єктів на інтенсивність спонтанної больової реакції в щурів з гострим карагеніновим артритом $(\mathrm{M} \pm \mathrm{m}, \mathrm{n}=40)$

\begin{tabular}{|c|c|c|c|}
\hline \multirow{2}{*}{$\begin{array}{c}\text { Об'єкт } \\
\text { дослідження }\end{array}$} & \multicolumn{2}{|c|}{ Індекс інвалідності, ум. од. } & \multirow{2}{*}{$\begin{array}{l}\text { Анальгетична } \\
\text { активність, \% }\end{array}$} \\
\hline & $\begin{array}{c}\text { вихідні } \\
\text { дані }\end{array}$ & $\begin{array}{c}2 \text { години після } \\
\text { введення препарату }\end{array}$ & \\
\hline \multicolumn{4}{|c|}{1 доба } \\
\hline Г/К крем-гель & $0,251 \pm 0,007$ & $0,354 \pm 0,009 \bullet / \#$ & $41,79 \pm 3,62^{\bullet} I^{\#}$ \\
\hline Фастум гель & $0,247 \pm 0,006$ & $0,337 \pm 0,007^{\bullet / \#}$ & $36,73 \pm 1,60^{\bullet / \#}$ \\
\hline Глюкозамін крем-гель & $0,253 \pm 0,006$ & $0,277 \pm 0,005$ & $9,88 \pm 1,29$ \\
\hline Хондроксид & $0,248 \pm 0,005$ & $0,277 \pm 0,005$ & $11,92 \pm 1,37$ \\
\hline \multicolumn{4}{|c|}{3 доба } \\
\hline Г/К крем-гель & $0,189 \pm 0,005$ & $0,279 \pm 0,007^{* / \bullet / \#}$ & $47,92 \pm 3,12^{* / \bullet / \#}$ \\
\hline Фастум гель & $0,183 \pm 0,004$ & $0,247 \pm 0,006 \bullet \%^{\#}$ & $35,34 \pm 1,46 \bullet /^{\#}$ \\
\hline Глюкозамін крем-гель & $0,185 \pm 0,004$ & $0,210 \pm 0,005$ & $13,43 \pm 1,14^{\bullet}$ \\
\hline Хондроксид & $0,187 \pm 0,005$ & $0,224 \pm 0,006$ & $19,65 \pm 0,83$ \\
\hline \multicolumn{4}{|c|}{5 доба } \\
\hline Г/К крем-гель & $0,295 \pm 0,005$ & $0,478 \pm 0,005^{* / \bullet / \#}$ & $62,23 \pm 2,61^{* / \bullet / \#}$ \\
\hline Фастум гель & $0,293 \pm 0,005$ & $0,416 \pm 0,007^{\bullet / \#}$ & $42,05 \pm 2,00^{\bullet / \#}$ \\
\hline Глюкозамін крем-гель & $0,295 \pm 0,007$ & $0,344 \pm 0,005$ & $17,06 \pm 1,67$ \\
\hline Хондроксид & $0,289 \pm 0,005$ & $0,350 \pm 0,006$ & $21,07 \pm 1,16^{\bullet}$ \\
\hline
\end{tabular}

Примітки:

1) * - відмінності вірогідні відносно тварин, що отримували препарат порівняння Фастум гель $(p \leq 0,05)$;

2) - відмінності вірогідні відносно тварин, що отримували препарат порівняння Глюкозамін крем-гель $(p \leq 0,05)$.

3) \# - відмінності вірогідні відносно тварин, що отримували препарат порівняння Хондроксид $(p \leq 0,05)$.

Висновки. 1. Комбінація глюкозаміну 3 кетопрофреном в фрормі крем-гелю при нашкірному застосуванні проявляє виражений анальгетичний вплив за умов розвитку спонтанної больової реакції у щурів 3 гострим карагеніновим артритом.

\section{Література}

1. Алексеева Л. И. Применение локальных средств в лечении остеоартроза/Л.И. Алексеева, Н. Г. Кашеварова // РМЖ. - 2008, № 24. - С. 1622-1628.

2. Зупанец И. А. Клинико-фрармацевтические аспекты современных комбинированных хондропротекторов / И. А. Зупанец, С. К. Шебеко // Consilium medicum - 2010. - Том 4 № 4. - С. 3-7.

3. Інструкція для медичного застосування препарату „Хондроксид” [Електронний ресурс]. - Наказ МОЗ України № 159 від 05.03.2014 - Режим доступу : http:// mozdocs.kiev.ua/likiview.php?id=34324

4. Коваленко В. Н. Остеоартроз. Практична настанова. / В. Н. Коваленко, О. П. Борткевич. - 3-тє вид., допов., зі змінами - К. : МOPIOH., 2010. - 608 с.

5. Международная классификация болезней 10-го пересмотра (МКБ-10) [Електронний ресурс].- Режим доступу: http://mkb-10.com/

6. Миронов А. Н. Руководство по проведению доклинических исследований лекарственных средств. Часть первая / А. Н. Миронов. - 2012. - 944 с.
2. За ступенем анальгетичного впливу досліджувана комбінація глюкозаміну 3 кетопрофеном вірогідно перевершує активність препарату порівняння Фастум гель на 3 та 5 добу, а також інших референс зразків протягом всього дослідження.

7. Настанова СТ-Н МОЗУ 42-6.0:2008. Лікарські засоби. Належна лабораторна практика (видання офіційне) / О. Стефранов, Т. Бухтіарова, В. Коваленко [та ін.] - К. : Моріон, 2009. - C. 37-68.

8. Остеоартроз: консервативная терапія : монография / под ред. Н. А. Коржа, Н. В. Дедух, И. А. Зупанца. - Х. : Золотые страницы, 2007. - 424 с.

9. Реброва О. Ю. Статистический анализ медицинских данных. Применение пакета прикладных программ STATISTICA / О. Ю. Реброва. - 3-е изд. - М. : МедиаСфрера, 2006. - 312 с.

10. Anti-inflammatory synergy of MEN16132, a kinin B2receptor antagonist, and dexamethasone in carrageenaninduced knee joint arthritis in rats / C. Valenti, S. Giuliani, C. Cialdai [et al.] // British Journal of Pharmacology. - 2010. - Vol. 161. - P. 1616-1627.

11. Data and statistics - Geneva, World Health Organization 2011 (http://www.euro.who.int/ru/what-we-do/health-topics/ Life-stages/healthy-ageing/data-and-statistics/10-facts-onhealthy-ageing-in-europe)

ISSN 2312-0967. Фармацевтичний часопис. 2015. № 2 
Фармакологічні дослідження біологічно активних речовин

Pharmacological researches of biologically active substances

12. Effect of intra-articular 4-(S)-amino-5-(4-\{4-[2,4-dichloro3-(2,4-dimethyl-8-quinolyloxymethyl)phenylsulfonamido]tetrahydro-2H-4-pyranylcarbonyl\} pipe $\neg$ razino)-5-oxopentyl] (trimethyl)ammonium chloride hydrochloride (MEN16132), a kinin B2 receptor antagonist, on nociceptive response in monosodium iodoacetate-induced experimental osteoarthritis in rats / C. Cialdai, S. Giuliani, C. Valenti [et al.] // Journal of Pharmacology and Experimental Therapeutics. - 2009. Vol. 331 (3). - P. 1025-1032.

13. EULAR evidence based recommendations for the diagnosis of knee osteoarthritis /W. Zhang, M. Doherty, G. Peat [et al.] // Ann. Rheum. Dis. - 2009. - Vol. 68, № 13. - P. 141.

14. European convention for the protection of vertebrate animals used for experimental and other scientific purpose: Council of Europe 18.03.1986. - Strasbourg, 1986. - 52 p. 15. Kissin E. Y. The effects of intraarticular resiniferatoxin in experimental knee-joint arthritis / E. Y. Kissin, F. C. Freitas, I. Kissin // Anesthesia \& Analgesia. - 2005. - Vol. 101. P. 1433-1439.

16. McDougall J. Vasoactive intestinal peptide (VIP) is a modulator of joint pain in a rat model of osteoarthritis/ J. J. McDougall, L.Watkins, Z. Li // Pain. - 2006. - Vol. 123 - P. 98-105.

17. Regulation of pain sensitivity in experimental osteoarthritis by the endogenous peripheral opioid system / J. J. Inglis, K. E. McNamee, Sh.-L. Chia [et al.] // Arthritis \& Rheumatism. - 2008. - Vol. 58, No. 10. - P. 3110-3119.

\title{
ИССЛЕДОВАНИЕ ВЛИЯНИЯ КОМБИНАЦИИ ГЛЮКОЗАМИНА С КЕТОПРОФЕНОМ В ФОРМЕ КРЕМ- ГЕЛЯ НА СПОНТАННУЮ БОЛЕВУЮ РЕАКЦИЮ У КРЫС
}

\author{
Н. В. Давишняя, И. А. Зупанец, С. К. Шебеко \\ Национальный фрармацевтический университет, Харьков
}

Резюме: исследование анальгетической активности комбинации глюкозамина с кетопрофеном в форме крем-геля было проведено на модели острого экспериментального артрита у крыс. По полученным данным, исследуемый препарат оказывает положительное влияние на течение спонтанной болевой реакции у крыс и имеет выраженную анальгетическую активность.

Ключевые слова: глюкозамин, кетопрофен, крем-гель, спонтанная болевая реакция, анальгетическая активность.

\section{THE RESEARCH OF INFLUENCE OF COMBINATION GLUCOSAMINE WITH KETOPROFEN IN THE FORM OF A CREAM-GEL TO SPONTANEOUS PAIN RESPONSES IN RATS}

\section{N. V. Davishnia, I. A. Zupanets, S. K. Shebeko \\ National University of Pharmacy, Kharkiv}

Summary: the study of analgesic activity of combination of glucosamine with ketoprofen in the form of a cream-gel was conducted on the model of acute experimental arthritis in rats. According to received information the studied drug has a positive effect on the course of spontaneous pain response in rats and has a pronounced analgesic activity.

Key words: glucosamine, ketoprofen, cream-gel, spontaneous reaction of pain, analgesic activity.

Отримано 24.03.2015

ISSN 2312-0967. Pharmaceutical review. 2015. № 2 